\title{
Science Education and Popularization of Science in the Biomedical Area: its Role for the Future of Science and of Society
}

\author{
Virgínia Schall \\ Instituto Oswaldo Cruz, Av. Brasil 4365, 21045-900 Rio de Janeiro, RJ, Brasil
}

This paper presents the main subjects discussed in the round-table: "Educational Base for Biomedical Research", during the International Symposium on Biomedical Research in the 21st century; two main aspects will be focused: (1) the importance of popularizing science in order to stimulate comprehension of the scientific process and progress, their critical thinking, citizenship and social commitment, mainly in the biomedical area, considering the new advances of knowledge and the resulting technology; (2) the importance to stimulate genuine scientific vocation among young people, by giving them opportunity to early experience scientific environment, throught the hands of well prepared master in a humanistic atmosphere.

Key words: science education - biomedical education - scientific formation - health education science and society

Before focusing the educational process in the biomedical area it is necessary to define education, which implies in understanding the progresses of the cognitive sciences, the educational theories, the historical and social factors that interfere in the educational process, the pedagogic practices, the influence of formal and informal teaching systems, teachers' formation, and the evolution of the knowledge of life sciences and its practical applications.

In relation to cognitive sciences, progresses have been significant in the last decades, concerning cognitive psychology and neurosciences. The interpretation of the cognitive processes for neurosciences developed greatly, facilitating the identification of cellular and molecular mechanisms of the learning process (Dudeck \& Bear 1992), the importance of emotion in the rational processes of decision makings, the role of sensorial experience in cerebral development, the several types of memory, and the neural correlation of perception and attention (Herculano-Houzel 1999).

Cognitive psychology observes and investigates the process of change of concepts, which means

Present address: Centro de Pesquisas René RachouFiocruz, Belo Horizonte, MG, Brasil

Fax: +55-31-295.3115

E-mail: vtschall@cpqrr.fiocruz.br

Received 7 August 2000

Accepted 4 September 2000 the way someone classifies something, or the way a concept can change its meaning through learning (Giere 1992). The term conceptual change presupposes the result and the process involved in the change. There are still previous subjects, about the existence or not of innate concepts, the construction of spontaneous concepts by children, the change of concepts for enrichment and the transformation of a concept into another incommensurably different from the original (Carey 1992).

While cognitive sciences aim at decoding the learning processes, the theories of the education build explanations on the action of educating, upon biological, psychological or social bases, or more recently under multi or cross-disciplinary, biopsycho-social focuses. In spite of several proposed educational theories researches in this area are rare (de Meis 1998), which could explain the low indexes of the publication of the Institute of Scientific Instruction on the theme, although this is not the best indicator, since social and human sciences researches are more discussed in books or other publications not indexed by that institution. Besides that, de Meis refers to the fact that teaching is treated as a routine activity in the universities, therefore dissociated of the research, development and experimentation of a new pedagogy which is restricted to the education colleges.

\section{WHAT IS TO EDUCATE AND WHAT IS EDUCATION GOOD FOR?}

Considering the biomedical area and the role of education in health, not only for professionals but also for the population, Humberto Maturana's recent work (1998), evidences his wonders: what 
is to educate and what is education good for? $\mathrm{He}$ explains the action of educating as a process and a coexistence space, where those that coexist change spontaneously, making their way of living more appropriate. When wondering about what education is good for, it is clear that "to serve" is a relational concept, since nothing serves itself. Thus, he concludes that the true subject is: what do we expect from education? Politically thinking, the educational project of each period and place can differ in its objectives according to the ideology and the several ways of executing social responsability. Maturana, himself, considering Chile when teached there, states that education had the commitment of accomplishing the fundamental task of ending with the poverty, with suffering, with the inequalities and the abuses.

Based on Maturana, Vaz (1999) leads us to other queries, when throwing a biological glance at the teaching activity and health. It is from the statement that living beings are determined by their structure, thus learning does not derive from some teaching method, but from living beings' structure. From this perspective, he affirms that there is no teaching, but coexistence and the teacher is the one who creates a coexistence environment and the relationship with the students is a domain of reciprocal acceptance that provides changes.

Paulo Freire (1992) reinforces this point of view, when states that man should be the subject of its own education, not the object, because education can not be impose, an internal movement of one's will is necessary. Communication settles down and the knowledge and values exchange takes place, in a dialogic process, where the teacher and the learner build the knowledge together. For the educator Freire, education in Latin-American societies is still vertical and, also, many times in health practices. Culturally teachers/professionals are still considered superior beings that educate/teach the illiterate person; students receive knowledge passively, becoming a deposit of the educator or professional. One educates to file what is deposited. In this way, one loses the power of creating and sharing. Man's destiny should be to create and to transform the world, being the subject of his action (Freire 1992).

Such idea goes with Vygotsky's thoughts (1991), about the nature of the learning process, that knowledge is built in a social context, in which each individual is affected significantly by the actions and ideas of the other. Thus, as suggests Poplin (1988), the educators that share a constructivist and holistic attitude, tend to emphasize the role of affection, intuition and sociopolitical forces in learning rather then content, although without depreciating it; being more attentive to personal in- terest, self-concept and the student's trust, stimulating them inside the context of their own experiences. Such educators are facilitators or "teachers learners", learning with their students, respecting their own capacity of learning. They recognize that the students will learn what is significant for them.

The coexistence space establishes marks in the field of education as a philosophy on the process of construction of the knowledge. They still promote a re-exam of the role of the education in a given society. Considering education as an effort, to aid the learner to build a knowledge that will make him capable of participating constructively in the society, to obtain personal satisfaction and self-accomplishment, will depend on the nature of each society, its problems and organization, the direction of the educational task. Thus, curricula should be structured to assist a double demand: society and the individual's desire of self-accomplishment, which does not always coincide (Guattari 1990). Specifically in the biomedical area, the curriculum should be organized in order to make students capable of understanding the world; it should be significant for his life. Teaching should be guided by the "discovery", the "insight", stimulating the curiosity, the reflection and the exchanging knowledge, increasing student's possibility of self-accomplishment and social commitment.

Besides, the teacher that stimulates group works from the most tender age, values the interaction among the pairs, as Forman and Cazden (1987) suggest, when demonstrating the advantages of that relationship for the internalization process and $\operatorname{cog}$ nitive development, under Vygotsky's perspective. The work among students favors the development of cooperation and responsibility, as demonstrated by Piaget $(1978,1988)$.

Another aspect to be considered is the importance of the popular knowledge and of questioning the authoritarian attitude sustained in the teachers' conception that place themselves in the position of a know-it-all and prejudice in relation to the student, who is considered as not knowing anything. Bezerra and Garcia (1986) criticize authoritarism, summed up to guided practices of "making other's head", evidencing the importance of considering the popular knowledge in educational situations. Ausubel (1968) explains this situation emphasizing the importance of the students' previous concepts, which are fundamental as a starting point to construct scientific concepts; he states that the most important isolated factor influencing the learning is what the learner already knows (Moreira \& Massini 1982). Through the storage of information in the human brain, conceptual hierarchies are formed, where more specific elements of knowledge are linked to more general concepts. 


\section{HISTORICAL AND SOCIAL FACTORS RELATED TO THE EDUCATIONAL PROCESS}

A wide and recent analysis of historical and social factors that interfere in the educational process, considering science education, is presented by de Meis (1998), who points out the super-specialization and excess of information as one of the problems which consequently generates the coexistence in the same community of people with different cultural ages. De Meis also states that the excess of information transforms the art of teaching into the art of reducing, condensing and simplifying - this simplification can generate serious conceptual mistakes - the teacher explains correctly and the student can absorb and register incorrectly.

Chaves and Schall (1999), discuss this superespecialization when compare the development of science and educational process in our society, and state that there are three factors involved: (1) the fragmentation of science; (2) the division between cognitive and affective aspects in school teaching; and (3) the new labor market tax due to globalization.

The economic division of the work and the growth of the cities contributed to the beginning of man's specialization in the sense of becoming unique and irreplaceble. Concerning this idea of fragmentation and separation, we can think about the dichotomy between cognitive and affective, which has generally characterized, formal teaching (Schall 1996). The cognitive knowledge still occupies a prominent place in the academic teaching. The several disciplines and their contents are the most important, and students recognition takes place through the evaluation of the degree of acquisition of those contents. It is as if our schools produced "experts" in knowledge that are, generally far from scientific, economic, politics or social reality.

In the ocidental society, the pragmatic and technocratic thought is generalized. Taking into consideration that new order, it is possible to think in a gap between Brazilian teaching and labor market. In general, schools have been preparing youngsters to functions that will be necessary in a near future; besides that, the number of vacancies in the formal labor market perhaps is not enough to employ the new generation. Teaching still emphasizes cognitive knowledge in detriment of students' sensibility, autonomy and creativity (Chaves \& Schall 1999).

This distance between the ideal of education and what it has become in practice in our society, is discussed by Lowenfeld and Brittain (1977): In our educational system do we really give emphasis to the human values? Or are we so obscured by material rewards that we did not recognize that the true values of democracy reside in its more precious possession - the individual?

This subject exposes the dichotomy between to possess and to be and finds resonance in the renascentist French philosopher, Montaigne, who, in the XVI century, discussed children's education. At that time, he already pointed out the inadequacy of parents' care expenses to fill children's head with science, leaving good sense and virtue sideways. He used to say that we always question if the individual knows Greek and Latin, if he writes in verse and prose, but we never ask if he became better and if his spirit was developed - questions that really matter (Montaigne 1580/1991). After tracing a series of practical suggestions, he concludes that teaching should begin in the emotional area and should be consolidated in the cognitive area. After telling the individual how to make him informed and better, they will tell him about logic, physics, geometry, and rhetoric; and since his intelligence will be already formed, he will be able to choose science he wants to learn (Montaigne 1580/1991).

It is necessary to consider that theories and methods need to be adapted to their time. But, education should maintain the challenge of critics and progress. Thus, although technology demands a practical and realistic spirit, this cannot be put upon what Montaigne tries to assure through his ideas, i.e. the strengthening of freedom, conscience and of the critical spirit. Education cannot be subjected to the immediate needs of its time, or else it will be reduced to the mere process or reproducing practice. It must be as a flame of new ideas, intermediating the past, the present and leading to the future. Stimulating criticism and creativity. Such position is shared by Freinet (1991) in his book Pedagogy of the Good Sense. He questions the scholastic and the "pretentious science", and the "content" of the teaching, defending that what is important is the teacher's attitude of "making the student be thirsty". He recommends: “... Stimulate your students to go as quick and far as possible. You need only to plan enough activities - fortunately, there are many -, to feed the need of creation and accomplishing (Freinet 1991).

Weiler (1991), although outlining some restrictions to Montaigne's placements, admits that the teaching of the XX century deserves good part of the censure that was addressed to the XVI century: abstraction, formalism, and verbalism. Weiler still values Montaigne's advice as to the rejection of any training type, emphasizing the importance of the free adhesion of the intelligence to the historical or scientific truth, the free adhesion of the consciences to the moral truth. 
THE ROLE AND THE POPULARIZATION OF SCIENCE IN OUR TIME, SPECIFICALLY IN THE BIOMEDICAL AREA

Science popularization in Brazil is still a quite unexplored area for the academic atmospheres and for the communication means in general. There are a few universities that maintain programs or publications to inform the public about the scientific knowledge developed in their laboratories. There are few specific television and radio programs or articles of newspapers and magazines, concerning science.

In general, scientific knowledge is restricted to the academic environment, but we hear scientists' arguments in defense of the enlargement of what they call: "scientific literacy" for the population, which would enable everyone to better understand the world where they live, enlarge their critical capacity and citizen participation, exercising better surveillance upon their own lives and society.

An important subject to be discussed with the public is about the intimate association between principles and scientific theories and its application, just as it is expressed by techno-science's concept. Techno-science, in the current civilization, became the main starting point to organize human life. Creation and conservation of knowledge demands fidelity in the production of truths; the extension and limits of technology, articulated with ethics are the central themes of contemporary reflection (Latour 1987), which should be enlarged for the lay public.

In that sense, scientific popularization becomes a social commitment, mainly concerning health and environment areas, which may enable children to develop a critical conscience in relation to himself, to the others and the world, and therefore, to techno-science.

That is, actually, a biunique action. The effort of translating and communicating scientific and technological production for the "common sense" has an inductive effect in the construction of knowledge and in the elevation of the scientific community's critical and ethical patterns. Ludwig Fleck (1986) discussed this in an original way. He highlighted the importance of the popularization of science for the progress of specialized knowledge. In the specialist and the layman struggle for communication, a new field of interaction is created with great potential for knowledge production.

Sharing the current concern on the role of science and its popularization in the current society, the periodic Science has been publishing a series of essays entitled: "Science and Society"; articles are ordered to eminent scientists, philosophers, epistemologists and even amateur specialists, which approach ethical, scientific, philosophical and political subjects concerning our present society.

Norman Augustine, engineering teacher at Princeton University, discusses, in one of those essays, scientific knowledge or illiteracy for mankind.

According to Augustine (1998), nowadays we may still hear the most absurd ideas on thoroughly known phenomena. In relation to the American society, Augustine reports a recent research of the National Foundation of Science, which showed that less than $50 \%$ of American adults understand that the earth rotates annually around the sun, $21 \%$, can define the DNA and only 9\% know what a molecule is. In another research it was shown that one out of seven Americans (about 25 million people) are not capable to point out the United States in a world map without legends. Dan Goldin, NASA's administrator, reports that, when claiming for financial support for the space agency, he heard: Why do we need to build meteorological satellites if we already have the Channel of the Time on TV?

These evidences are not limited to the United States. According Augustine, the main character in an English piece states that: First comes religion and art, soon after comes philosophy, and at last, comes science. This is the order of importance of the great subjects about life in the current society. Augustine points out the irony of this evidence; more than in any other country on Earth, American economy and its life pattern are based on scientific progress. As it is said, what separates us from our prehistoric ancestors, in their caves, is the product of science and of its correlate, technology.

In spite of all scientific progress and constant technological innovations, Augustine ponders on the challenge that remains in the field he calls "social-science". For a great part of the population, science is associated to disasters as Chernobyl, Bhopal, Thalidomide, Challenger, and the atomic bomb. Science is seen as a source of problem not solution, as something to be avoided or braked.

This discussion is heated up today, above all, in the biomedical area, with the coming of the artificial insemination and of the transgenic products. What is debated is linked to the possibilities of generating monsters and menaces to the man and to the society. But which father or mother would leave his/her son to die instead of receiving a transplanted heart, grown in a transgenic pig? Which diabetic individual would not like to be drinking the milk of transgenic goats, that already brings insulin? Definitively, laws will be necessary to control human activity, to predict menaces and individual ravings. However, aversion to technology, 
does not derive from knowledge, but from the lack of it.

According to Augustine, scientists consider themselves as descendents of Benjamin Franklin's model, a benevolent inventor, who contributed to improve mankind's quality of life; but they are frequently noticed as "Dr Frankenstein", capable of spreading terror and deformations through the world. Scientists today must face political and social forces and Augustine proposes a Second Law of Social Science, which establishes that: For each scientific action, there is an opposite and equal reaction. Thus, more and more, any occasional flaw of the science will be submitted to the intense public criticism, although supported by the illiteracy among those that command the elite of decision in the society. Augustine exemplifies the small number of American deputies and senators (20 among 453 ) and governors (9 in 50) with some knowledge in science, which have the power of decision on subjects as space programs, cloning, project of the human genome, etc. The damage can be enormous, when who decides on our welfare is not capable of understanding rudimentary scientific aspects on critical subjects. And here Augustine wonders: Can the Americans choose appropriate leaders to support their programs if they are scientifically illiterate?

It seems that, at least in the American society, there is a growing movement for the popularization of science, with the creation of science museums and science centers, as well as science initiation programs for children and youngsters. In Brazil, this movement has also progressed. Sharing this tendency, in 1986, the Oswaldo Cruz Foundation created the Program of Scientific Vocation (Provoc) and in 1999 inaugurated the Museum of Life.

\section{THE IMPORTANCE OF SCIENTIFIC EDUCATION AND THE RELATIONSHIP TEACHER/STUDENT}

Among the several activities proposed to enlarge the understanding of science and scientific vocations, the initiation programs preconize that the precocious experience can develop a more genuine motivation, as well as the relationship with a well prepared master can stimulate scientific competence associated with human values as equality, solidarity and ethics.

Presently, psychologists have turned their focus to investigation of how some children become musicians, poets, scientists or painters, and others do not, and why these capacities either develop or atrophy in determined cultures. They try to find out how creativity and scientific interest develop.

Simonton (1978), in his book, Scientific Genius, describes several researches carried out with scientists, in which it was verified that most of those who were productive during all their career began early, having received their degrees when very young, assuming the habit of regular production ever since.

Another point to be discussed is the importance of interaction with masters which became models for some renowned national and international scientists.

In Howard Gardner's book, Creating Minds (1996), we find examples of important people as Freud, Einstein, Picasso, Stravinsky, Eliot, Graham and Gandhi; who cite the strong presence of a master or a model in the childhood and/or adolescence hood or a stimulating school and important readings. It is worth to highlight Gardner's arguments on the importance of having a stimulating person side by side with the child to guide her through a comfortable, exploiting experience, that results in a "capital creativity", which certainly will be worth for a lifetime. Gardner mentions a study by Benjamin Bloom and Luren Sosniak, were they identify the moment talent individuals fell in love with a material, a situation or a specific person, whose attraction mobilizes his/her potential in search for accomplishment, being characterized as a "crystallizing experience"; which should be a favorable situation in our youths' scientific initiation, stimulating the vocation and motivation for the scientific performance.

Among Gardner's choice, let us take a glance over Freud and Einstein to the beginning of their scientific formation.

In relation to Freud, Gardner highlights Ernst Bruecke as the first master that influenced Freud. Bruecke rejected any consideration of vitalism or intention of the living matter, believing that the answers for all natural questions should come from the careful study of the cells and their connections, and from the specification of the chemical and physical forces that control their biological interactions. That was the ideological atmosphere where Freud was thrown, having as a first task to study the histology of a peculiar type of a big cell of Petromyson, a primitive fish, as well as the structures of the nervous cells of the shrimp-of-sweetwater and the gonad of the eel. In these first experiences, Freud accomplished his first invention, creating a method to color the nervous tissue with yellow-golden chloride.

Gardner highlights that besides the scientific knowledge and technical abilities acquired by Freud, Bruecke's personality impressed him. However demanding, he demonstrated enthusiasm and supported the students that managed to follow his scientific and personal example. From Bruecke, Freud adopted the faith in the materialistic expla- 
nations and shared his disdain for the mystic, he also developed the capacity to observe details, as he analyzed the organization of the nervous system. Besides Bruecke, Gardner also includes the neurologist Jean-Martin Charcot as an important influence in Freud's formation. Charcot was an expansible and charismatic man and in a letter from Freud to his bride, he reveals that some day he would possibly reach Charcot's level.

Concerning Einstein, his questions remind those of small children, when they are not habitually "silenced" by the adults. Besides, he watched, in his childhood, the father and the brother building a variety of electric devices, which arouse up his curiosity for machines of all types and constructions that he reproduced with toy elements. In his youth, a Russian-Jewish medicine student that used to visit his parents' house influenced Einstein, by given him many books, including classicals from Kant and Darwin. Also publications of Aaron Bernstein, a type of Isaac Azimov of those times, where a vision of mechanic science and atomistic were presented. It stimulated his faith in the potential of the scientific research. Although it is well known that Einstein was a weak and disinterested student in the school during his childhood, in his adolescence he adored the teaching establishment where he studied. It was a progressive school, strongly influenced by Johann Pestalozzi's pedagogic philosophy, where a humanistic approach was stimulated, as well as the centralization of the visual understanding for the formation of concepts. Once he stated that: The school left in me an unforgettable impression, thanks to its liberal spirit and to the teachers' pure dedication, that wasn't based upon any external authority.

Gardner also refers to the reading of a book written by an obscure physics teacher, August Foppl, that Einstein devoured in 1890 and it seems to have helped him to understand that mechanics is a part of the physics, and that the investigation of those topics embraces philosophical and epistemological subjects that cannot be ignored. Foppl wrote that book so that the students without a formal training could understand some scientific principles of physics, in which Einstein could identify some of his more persistent concerns.

We can notice the influence of people, readings, and a stimulating environment, associated to a born curiosity in Freud's and Einstein's scientific formation. In the Brazilian science, we can also find examples of masters' remarkable influence and stimulating atmospheres, which are decisive for the entrance and the continuity in the scientific career.

In an interview with Professor Hortênsia de Hollanda (Schall 1999), she reveals the influence of her father, Horácio Hurpia Filho, physician, whom she accompanied through public hospitals and outskirts communities, attended by him on the weekends. As she describes it: his capacity to hear the complaints of the sick people, his will to understand the cause of diseases, to penetrate the root of the factors before intervening, showed a professional behavior that marked me deeply, associated to the respect and solidarity to the suffering of the people. Those were attitudes that marked his practice, important for health education, an area in which to hear the population and to build the action programs with it is a must, which Hortênsia practices and teaches for a lifetime, since she began.

Another important declaration which illustrates the productive relationship master-student, was left by Dr Hugo de Souza Lopes, one of the most quoted Brazilian entomologists, researcher at the Oswaldo Cruz Foundation. In his interview to my book, Fact Tales (Schall unpub. data), in 1989, he told that his own option for the scientific career happened, not for an ideal or tendency from childhood, but due to his encounter with Prof. Lauro Travassos, a master that could unveil his vocation and interest for science.

Dr Hugo attended the 2nd year of the veterinary course when he met Prof. Travassos. It was August 1931; he was 22 years old. Prof. Travassos invited him to a professional training in Manguinhos where he stayed until the end of 1949, when he was finally admitted.

As a student of Prof. Travassos in the discipline of Medical Zoology, he was the brightest in his group, and was indicated, in 1933, to be assistant of this Chair, position that he exercised until 1938. Dr Hugo talks about Prof. Travassos, highlighting his simplicity, his faith in the learning capability of everyone. This admiration and friendship, according to Dr Hugo, motivated his dedication to teaching activity and scientific investigation.

Dr Hugo motivated the scientific vocation of countless students, among them, Dr Sebastião José de Oliveira, also a researcher at the Oswaldo Cruz Foundation, that described the importance of learning and coexistence with his master, when they set out for collection of animals in the forest of Grajaú, Rio de Janeiro. As he describes it: There I learned almost everything that I know today, besides botany, with the coexistence, the experience and the teachings of Prof. Hugo. We were there until midday, one o'clock in the afternoon, observing, collecting insects and sometimes plants. After lunch, we used to go to a room on top of the garage, where the professor had his laboratory/office/library, where we prepared the material col- 
lected during the day. By four o'clock, or five in the afternoon I returned home, happy for what I had collected and learned.

For all we said, it is clear the master's influence, the importance of the admiration arouse in the student, the character example, the ethics, the fidelity to the data, the honesty in the methodology and the pleasure in the investigation. It is also important the learning environment in school or in the laboratory and even at home. Upon all examples, remains the image of true human encounters and the enlargement it promotes on the formation of the young beginner, not only collaborating for a qualified scientific formation, but also for noble human values and commitment to life, the society and the counterparts.

\section{REFERENCES}

Augustine N 1998. What we don't know does hurt us how scientific illiteracy hobbles society. Science 279: 1640-1641.

Ausubel DP 1968. Educational Psychology: a Cognitive View, Holt, Rinehart \& Winston, New York, $685 \mathrm{pp}$.

Bezerra A, Garcia PB 1986. Conversando com os agentes. Cadernos de Educação 3: 9-31.

Carey C 1992. The origin and evolution of everyday concepts. In RN Giere, Cognitive Models of Science, University of Minnesota Press, Minneapolis, p. $89-128$.

Chaves JC, Schall VT 1999. Exploratory study on perception and emotion: a tool for the implantation of an experimental thematic space in a museum of science in Brazil. Proceedings of the 9th IOSTE Symposium, Durban, South Africa, Vol I, p. 81-85.

de Meis L 1998. Ciência e Educação. O Conflito Humano-Tecnológico, Ed. do Autor, Rio de Janeiro, $200 \mathrm{pp}$.

Dudek SM, Bear MF 1992. Homosynaptic long-term depression in area CA1 of hippocampus and effects of N-methyl-D-aspartate receptor blockade. Proc Natl Acad Sci USA 89: 4363-4367.

Fleck L 1986. Some specifics features of the medical way of thinking. In RS Cohen, T Schenelle (eds), Cognition and Fact: Materials on Ludwik Fleck, D. Reidel, Dordrecht, p. 39-46.

Forman EA, Cazden CB 1987. Exploring Vygotskian perspectives in education: value of the peer interaction. In JV Wertsch, Culture, Communication and Cognition: Vygotskian Perspectives, Cambridge University Press, Cambridge, p. 323-347.

Freinet C 1991. Pedagogia do Bom Senso, Livraria
Martins Fontes Editora Ltda, São Paulo, 125 pp.

Freire P 1992. Pedagogia da Esperança: Um Reencontro com a Pedagogia do Oprimido, Paz e Terra, São Paulo, 245 pp.

Garcia PB 1986. Saber Popular/Educação Popular. Cadernos de Educação 3: 33-62.

Gardner H 1996. Mentes que Criam, Artes Médicas, Porto Alegre, $380 \mathrm{pp}$.

Giere R N 1992. Cognitive Models of Science, University of Minnesota Press, Minneapolis, 508 pp.

Guattari F 1990. As Três Ecologias, Papirus Editora, Campinas, $56 \mathrm{pp}$.

Herculano-Houzel S 2000. Você conhece o seu cérebro? O que o público pensa, conhece ou ignora. Anais da $52^{\mathrm{a}}$. Reunião da SBPC, Brasília.

Latour B 1987. Science in Action. How to Follow Scientists and Engineers through Society, Havard University Press, Cambridge.

Lowenfeld V, Brittain WL 1977. Desenvolvimento da Capacidade Criadora, Mestre Jou, São Paulo, 98 pp.

Maturana H 1998. Emoções e Linguagem na Educação e na Política, Editora UFMG, Belo Horizonte, 99 pp.

Montaigne M 1991. Ensaios, Ediouro/Editora Globo, Rio de Janeiro, 778 pp.

Moreira MA, Massini EFS 1982. Aprendizagem Significativa: a Teoria de David Ausubel, Editora Moraes, São Paulo, 112 pp.

Piajet J 1978. A Formação do Símbolo na Criança, Zahar, Rio de Janeiro, 370 pp.

Piaget J 1988. Para Onde vai a Educação? José Olympio, Rio de Janeiro, 80 pp.

Poplin MS 1986. Holistic/constructivist principles of the teaching/learning process: implications for the field of learning disabilities. J Learning Disabilities 21: 401-416.

Schall VT 1996. Saúde e Afetividade na Infância: o que as Crianças Revelame a sua Importância na Escola, $\mathrm{PhD}$ thesis, Department of Education, Catholic University of Rio de Janeiro, Rio de Janeiro, 343 pp.

Schall 1999. Alfabetizando o corpo: o pioneirismo de Hortênsia de Hollanda na educação em saúde. Cad Saúde Púb (Supl.) 15: 149-159.

Simonton DK 1988. Scientific Genius: a Psychology of Science, Cambridge University Press, New York, $229 \mathrm{pp}$.

Vaz N 1999. O ensino e a saúde: um olhar biológico. Cad Saúde Púb (Supl.) 15: 169-176.

Vygotsky LS 1991. A Formação Social da Mente, Martins Fontes, São Paulo, 167 pp.

Weiler M 1991. Para conhecer o pensamento de Montaigne. In P Moreau, Montaigne; o Homem e a Obra, Ediouro/Ed. Globo, Rio de Janeiro, p. 507575. 